\title{
双膦配体修饰铑催化乙酸乙烯酯氢甲酰化反应
}

\author{
梁浩然, 张 林, 郑学丽, 付海燕, 袁茂林, 李瑞祥, 陈 华* \\ 四川大学化学学院绿色化学与技术教育部重点实验室, 四川成都 610064
}

\begin{abstract}
摘要: 研究了双膦配体对铑催化的乙酸乙烯酯氢甲酰化反应的促进作用, 结果表明, 在优化反应条件下, 以双膦化合物 $2,2^{\prime}$-二 (二苯膦甲基) - $1,1^{\prime}$-联苯 (BISBI) 为配体时, 铑催化乙酸乙烯酯氢甲酰化反应的 TOF (转化频率) 值达到 $4000 \mathrm{~h}^{-1}$, 生成 2-乙酰氧 基丙醛的选择性 $>99 \%$. 当在较温和的条件下 $\mathrm{Rh} / \mathrm{BISBI}$ 催化乙酸乙烯酯氢甲酰化反应较长时间时 TON (转化数) 值达到 9200 , 成醛率超过 $90 \%$, 2-乙酰氧基丙醛选择性仍保持 > $99 \%$.
\end{abstract}

关键词: 乙酸乙烯酯; 氢甲酰化; 区域选择性; 双膦配体；2-乙酰氧基丙醛

中图分类号: O643 文献标识码: A

收稿日期: 2011-12-30. 接受日期: 2012-03-07.

*通讯联系人。电话/传真: (028)85412904; 电子信箱: scuhchen@163.com

本文的英文电子版(国际版)由Elsevier出版社在ScienceDirect上出版(http://www.sciencedirect.com/science/journal/18722067).

\section{Regioselective Rhodium-Diphosphine Ligand Catalyzed Hydroformylation of Vinyl Acetate}

\author{
LIANG Haoran, ZHANG Lin, ZHENG Xueli, FU Haiyan, YUAN Maolin, LI Ruixiang, CHEN Hua* \\ Key Laboratory of Green Chemistry and Technology of Ministry of Education, College of Chemistry, Sichuan University, \\ Chengdu 610064, Sichuan, China
}

\begin{abstract}
Rhodium-catalyzed hydroformylation of vinyl acetate with the use of diphosphine ligands was studied. A high regioselectivity (branched:linear of 99:1) and activity (TOF: $4000 \mathrm{~h}^{-1}$ ) under optimum conditions were achieved by using a 2,2'-bis(diphenylphosphino methyl)-1,1'-biphenyl ligand. The high turnover number (9200) obtained under mild conditions and stability of the catalyst indicates that it would be useful for industrial vinyl acetate hydroformylation.
\end{abstract}

Key words: vinyl acetate; hydroformylation; regioselectivity; diphosphine ligand; 2-acetoxypropanal

Received 30 December 2011. Accepted 7 March 2012.

*Corresponding author.Tel/Fax:+86-28-85412904; E-mail:scuhchen@163.com

English edition available online at Elsevier ScienceDirect (http://www.sciencedirect.com/science/journal/18722067).

Rhodium-catalyzed hydroformylation is an important reaction in academic research and industry [1]. Much effort has been devoted to the hydroformylation of functional olefins to give bifunctional products with greater added values [2-5]. For example, the hydroformylation of industrial vinyl acetate gives 1,2- and 1,3-bifunctional products with wide applications [6-8] (Scheme 1). However, due to the chelating effect of the ester carbonyl [9], there has been limited progress in this area, and there are few results with acceptable selectivity and rates. Williams et al. [10] reported that the hydroformylation of vinyl acetate in ionic liquids gave satisfactory results, but the complex procedure needed for the preparation of the ionic liquid is a limitation [11]. Recently, Dabbawala et al. [12] reported good catalytic activity with the use of a bulky phosphite, tri-1-naphthylphosphite $\left(\mathrm{P}(\mathrm{ONp})_{3}\right)$, as a ligand for the Rh-catalyzed hydroformylation of vinyl acetate, and they demonstrated that the ligand strongly influenced the catalytic performance of the rhodium complex. An important drawback of phosphite ligands is their instability, which limits their practical application [13].

We have previously reported on the hydroformylation of high added value functional olefins [14]. The results showed that bidentate phosphine ligands such as bis-3,4-di- 


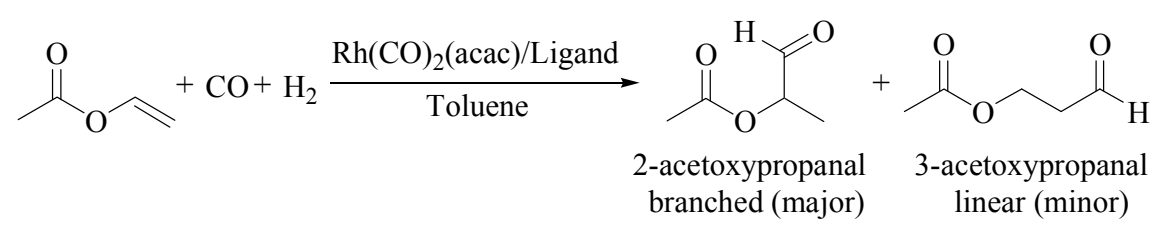

Ligands:

BISBI<smiles>c1ccc(-c2ccc3ccccc3c2-c2c(-c3ccccc3)ccc3ccccc23)cc1</smiles>

BINAP<smiles>COc1cc(-c2ccccc2)c(-c2c(-c3ccccc3)cc(OC)nc2OC)c(OC)n1</smiles>

P-Phos

Scheme 1. Hydroformylation of vinyl acetate. BINAP-2,2'-bis(diphenylphosphino)-1,1'-binaphthyl; P-Phos-2,2',6,6'-tetramethoxy-4,4'bis(diphenylphosphino)-3,3'-bipyridine.

azaphospholanes gave good regio- and enantioselectivities in the asymmetric hydroformylation of vinyl acetate [15-18]. And the use of sulfonated 1,1'-bis(diphenylphosphinomethyl)-2,2'-biphenyl (BISBIS) as a ligand in Rh-catalyzed biphasic hydroformylation of high olefins gave good results [19-21], which suggested that we can use the commercially available diphosphine 1,1'-bis(diphenylphosphinomethyl)-2,2'-biphenyl (BISBI) [22] in Rh- catalyzed homogeneous hydroformylation of vinyl acetate. The satisfactory catalytic activity, excellent regioselectivity for 2-acetoxypropanal (branched aldehyde), and high turnover number (TON) that were obtained showed the practical potential of diphosphine ligands in this reaction.

\section{Experimental}

All hydroformylation reactions were carried out in a stainless steel autoclave of $60 \mathrm{ml}$ stirred with a magnetic stirrer. A typical procedure was as follows. A toluene solution of $\mathrm{Rh}(\mathrm{CO})_{2}$ (acac) [23], ligand, and vinyl acetate was added to the autoclave, which was subsequently evacuated and purged with synthesis gas three times. The autoclave was then pressurized with synthesis gas and stirred at the reaction conditions. After the reaction was completed, the autoclave was cooled quickly to room temperature in an ice-water bath, and then vented slowly. The reaction mixture was immediately analyzed on a HP 9710 gas chromatograph equipped with an FID detector and a capillary column $(25 \mathrm{~m}$ $\times 0.53 \mathrm{~mm}$ ) CP-SIL $5 \mathrm{cb}$. The products were identified by GC-MS and ${ }^{1} \mathrm{H}$ NMR spectroscopy.

\section{Results and discussion}

BISBI was chosen as the ligand to investigate the effect of the reaction parameters on the Rh-catalyzed hydroformylation of vinyl acetate. The branched aldehyde was the main product, with propanal, acetic acid, and a marginal amount of 2-acetoxypropanol as side products. To our surprise, no linear aldehyde (3-acetoxypropanal) was detected in all the experiments.

\subsection{Effect of reaction temperature}

Previous studies on the kinetics demonstrated that the temperature plays a key role in the hydroformylation of vinyl acetate [24], thus the influence of temperature on the activity and selectivity of the $\mathrm{Rh} / \mathrm{BISBI}$ catalyzed vinyl acetate hydroformylation was first investigated in the range of $80-120^{\circ} \mathrm{C}$. As shown in Table 1, the reaction rate was low at $80^{\circ} \mathrm{C}$ although a high regioselectivity was observed. The increase in temperature from 80 to $120^{\circ} \mathrm{C}$ led to a large increase in reaction rate. However, the chemoselectivity decreased from $95 \%$ to $81 \%$, with propanal as the main byproduct. This was explained by that a high temperature favored the direct reaction of vinyl acetate with the rhodium

Table 1 Effect of temperature on Rh-catalyzed hydroformylation of vinyl acetate with BISBI as ligand

\begin{tabular}{ccccc}
\hline Entry & $\begin{array}{c}\text { Temperature Conversion } \\
\left({ }^{\mathrm{a}} \mathrm{C}\right)\end{array}$ & $\begin{array}{c}\text { Chemoselectivity }^{\mathrm{b}} \\
(\%)\end{array}$ & $\begin{array}{c}\text { Regioselectivity } \\
\end{array}$ \\
\hline 1 & 80 & 25 & 95 & $>99$ \\
2 & 90 & 52 & 92 & $>99$ \\
3 & 100 & 76 & 90 & $>99$ \\
4 & 110 & 96 & 90 & $>99$ \\
5 & 120 & 96 & 81 & $>99$ \\
\hline
\end{tabular}

Reaction conditions: vinyl acetate $=5.4 \mathrm{mmol},[\mathrm{Rh}]=1.4 \mathrm{mmol} / \mathrm{L}$, $\mathrm{S}: \mathrm{C}=2000,30 \mathrm{~min}, 4 \mathrm{MPa}\left(\mathrm{CO}: \mathrm{H}_{2}=1\right),[\mathrm{BISBI}]:[\mathrm{Rh}]=1$.

${ }^{\mathrm{a} C o n v e r s i o n}$ of vinyl acetate. ${ }^{\mathrm{b}}$ Selectivity for 2-acetoxypropanal and 3-acetoxypropanal. ${ }^{\mathrm{c}}$ Molar ratio of branched to linear aldehyde. 
hydride complex to ethylene and acetic acid [9], and ethylene was converted to propanal under the hydroformylation conditions.

To have a high reaction rate and acceptable chemoselectivity, $110^{\circ} \mathrm{C}$ was chosen as the reaction temperature for the following experiments.

\subsection{Effect of pressure}

The total pressure of $\mathrm{CO} / \mathrm{H}_{2}$ is also a key element in the hydroformylation of vinyl acetate. As shown in Table 2, under low pressure, both reaction rate and chemoselectivity were low. Increasing the pressure from 2 to $6 \mathrm{MPa}$ greatly improved the reaction rate (no substrate was detected at 6 $\mathrm{MPa}$ ), and increased the chemoselectivity. The carbonyl group of vinyl acetate hindered the insertion of $\mathrm{CO}$ into the $\mathrm{Rh}-\mathrm{R}$ bond of the rhodium complex to give the active intermediate $\mathrm{Rh}-\mathrm{COR}$, which slowed down the reaction rate. A higher pressure weakens the hindrance to $\mathrm{CO}$ insertion and improves the reaction rate. In addition, more $\mathrm{CO}$ and $\mathrm{H}_{2}$ inhibited the direct reaction of vinyl acetate with the rhodium complex to produce ethylene, and suppressed the formation of the propanal byproduct.

Table 2 Effect of pressure on Rh-catalyzed hydroformylation of vinyl acetate with BISBI as ligand

\begin{tabular}{ccccc}
\hline Entry & $\begin{array}{c}\text { Pressure } \\
(\mathrm{MPa})\end{array}$ & $\begin{array}{c}\text { Conversion } \\
(\%)\end{array}$ & $\begin{array}{c}\text { Chemoselectivity } \\
(\%)\end{array}$ & Regioselectivity \\
\hline 1 & 2 & 72 & 80 & $>99$ \\
2 & 3 & 90 & 87 & $>99$ \\
3 & 4 & 96 & 90 & $>99$ \\
4 & 5 & 99 & 91 & $>99$ \\
5 & 6 & 100 & 93 & $>99$ \\
\hline
\end{tabular}

Reaction conditions: vinyl acetate $=5.4 \mathrm{mmol},[\mathrm{Rh}]=1.4 \mathrm{mmol} / \mathrm{L}, \mathrm{S}: \mathrm{C}$ $=2000,30 \min , 110^{\circ} \mathrm{C},[\mathrm{BISBI}]:[\mathrm{Rh}]=1$.

\subsection{Effect of molar ratio of ligand to $\mathrm{Rh}$}

The effect of the concentration of ligand on the conversion and selectivity of vinyl acetate hydroformylation was studied by varying the molar ratio of BISBI to Rh from 1 to 3. The results are shown in Table 3. A higher concentration of the ligand decreased the conversion and chemoselectivity, and increased the formation of the propanal byproduct. An excess of BISBI prevents the catalyst from disassociating the catalytic active species, and so the reaction rate declined. In addition, increased stereo resistance of the catalytic active species due to an excess of BISBI was also detrimental for the conversion of coordinated vinyl acetate to an alkyl-Rh complex in the catalytic cycle and slowed down the reaction rate. At the same time, this would boost the direct reaction of vinyl acetate with the rhodium hydride
Table 3 Effect of molar ratio of BISBI to Rh on Rh-catalyzed hydroformylation of vinyl acetate with BISBI as ligand

\begin{tabular}{ccccc}
\hline Entry & $\begin{array}{c}\text { BISBI/Rh } \\
(\mathrm{mol} / \mathrm{mol})\end{array}$ & $\begin{array}{c}\text { Conversion } \\
(\%)\end{array}$ & $\begin{array}{c}\text { Chemoselectivity } \\
(\%)\end{array}$ & Regioselectivity \\
\hline 1 & 1 & 99 & 91 & $>99$ \\
2 & 2 & 51 & 81 & $>99$ \\
3 & 3 & 40 & 68 & $>99$ \\
\hline
\end{tabular}

Reaction conditions: vinyl acetate $=5.4 \mathrm{mmol},[\mathrm{Rh}]=1.4 \mathrm{mmol} / \mathrm{L}$, $\mathrm{S}: \mathrm{C}=2000,30 \mathrm{~min}, 110^{\circ} \mathrm{C}, 5 \mathrm{MPa}\left(\mathrm{CO}: \mathrm{H}_{2}=1\right)$.

complex to form ethylene and acetic acid [9] and increased the formation of the propanal byproduct. A similar observation had been reported in the iridium-catalyzed hydroformylation of olefins [25].

\subsection{Effect of catalyst concentration}

The effect of the catalyst concentration was studied. The results are shown in Table 4 . When the concentration of rhodium was increased from 0.9 to $1.4 \mathrm{mmol} / \mathrm{L}$, the reaction rate was also increased. Further increase in the concentration of rhodium from 1.4 to $2.2 \mathrm{mmol} / \mathrm{L}$ gave lower reaction rates. Since the concentration of vinyl acetate was increased (substrate to catalyst ratio was kept constant), this was probably due to that the inhibition effect on the reaction rate from the ester carbonyl group was enhanced. The decrease of chemoselectivity may be due to that the higher concentration of rhodium gave more of the direct reaction of vinyl acetate with the rhodium hydride complex to ethylene, which gave the byproduct propanal under the hydroformylation conditions.

Table 4 Effect of concentration of catalyst on Rh-catalyzed hydroformylation of vinyl acetate with BISBI as ligand

\begin{tabular}{ccccc}
\hline Entry & $\begin{array}{c}{[\mathrm{Rh}] /} \\
(\mathrm{mmol} / \mathrm{L})\end{array}$ & $\begin{array}{c}\text { Conversion } \\
(\%)\end{array}$ & $\begin{array}{c}\text { Chemoselectivity } \\
(\%)\end{array}$ & Regioselectivity \\
\hline 1 & 0.8 & 90 & 89 & $>99$ \\
2 & 1.4 & 99 & 91 & $>99$ \\
3 & 2.2 & 94 & 83 & $>99$ \\
\hline
\end{tabular}

Reaction conditions: toluene $=1.5 \mathrm{ml}, \mathrm{S}: \mathrm{C}=2000,30 \mathrm{~min}, 110^{\circ} \mathrm{C}, 5$ $\operatorname{MPa}\left(\mathrm{CO}: \mathrm{H}_{2}=1\right),[\mathrm{BISBI}]:[\mathrm{Rh}]=1$.

\subsection{Effect of diphosphine ligands}

The high regioselectivity and high activity when BISBI was used prompted us to test other available diphosphine ligands in the $\mathrm{Rh}$-catalyzed hydroformylation of vinyl acetate. As shown in Table 5, when BINAP and P-Phos were used as the ligand, better selectivities were obtained as compared with when monodentate ligands were used $[7,12]$. However, both BINAP and P-Phos gave lower activities than BISBI under the same reaction conditions. On com- 
Table 5 Effect of phosphine ligand on Rh-catalyzed hydroformylation of vinyl acetate

\begin{tabular}{ccccc}
\hline Entry & Ligand & $\begin{array}{c}\text { Conversion } \\
(\%)\end{array}$ & $\begin{array}{c}\text { Chemoselectivity } \\
(\%)\end{array}$ & Regioselectivity \\
\hline 1 & BISBI & 99 & 91 & $>99$ \\
2 & BINAP & 90 & 94 & $>99$ \\
3 & P-Phos & 83 & 95 & $>99$ \\
\hline
\end{tabular}

Reaction conditions: vinyl acetate $=5.4 \mathrm{mmol},[\mathrm{Rh}]=1.8 \mathrm{mmol} / \mathrm{L}$, $\mathrm{S}: \mathrm{C}=2000,30 \mathrm{~min}, 110^{\circ} \mathrm{C}, 5 \mathrm{MPa}\left(\mathrm{CO}: \mathrm{H}_{2}=1\right)$, ligand: $\mathrm{Rh}=1$.

paring the 7-membered P-Rh-P ring of BINAP or P-Phos with the 9-membered $\mathrm{P}-\mathrm{Rh}-\mathrm{P}$ ring of $\mathrm{BISBI}$, it is probable that the latter was more efficient in inhibiting the coordination of another carbonyl onto $\mathrm{Rh}$ to form the intermediate (7) (see Section 2.6, Scheme 2). And with the latter, the rate determining step, which is the oxidative addition of $\mathrm{H}_{2}$ to the intermediate $(\mathbf{8})$, would be more rapid and it gave a higher conversion.

\subsection{Reaction mechanism}

In previous studies, diphosphines with chelate bite angles close to $120^{\circ}$, such as BISBI (bite angle of $112^{\circ}$ ), were shown to give a high regioselectivity to linear aldehydes from terminal olefins [26]. However, a reversed regioselectivity (branched:linear > 99) was found in vinyl acetate hydroformylation with diphosphine ligands. Therefore, it can be supposed that the chelating effect from the ester carbonyl of vinyl acetate dominated the regioselectivity, where a more stable intermediate with a five-membered ring (5) via the anti-Markovnikov addition of $\mathrm{Rh}-\mathrm{H}$ to vinyl acetate is preferentially formed to give the branched aldehyde, 2-acetoxypropanal (Scheme 2). By considering the better regioselectivity that was obtained as compared to that obtained with monodentate ligands [7], it can be inferred that the diphosphine ligand has more steric bulk in the rhodium complex, which encouraged the formation of $\mathrm{Rh}$-(branched alkyl) (5), and is responsible for forming the branched aldehyde. The mechanism for the formation of propanal and acetic acid is still unclear. They could be formed by the decomposition of 3-acetoxypropanal or by the direct reaction of vinyl acetate with the rhodium hydride complex 1 [9]. Because no 3-acetoxypropanal was observed in all the experiments, the possibility of the decomposition of 3 -acetoxypropanal was excluded. Thus it is likely that the byproducts (propanal and acetic acid) were formed by the direct reaction of vinyl acetate with the rhodium hydride complex 1, as reported in the literature [9].

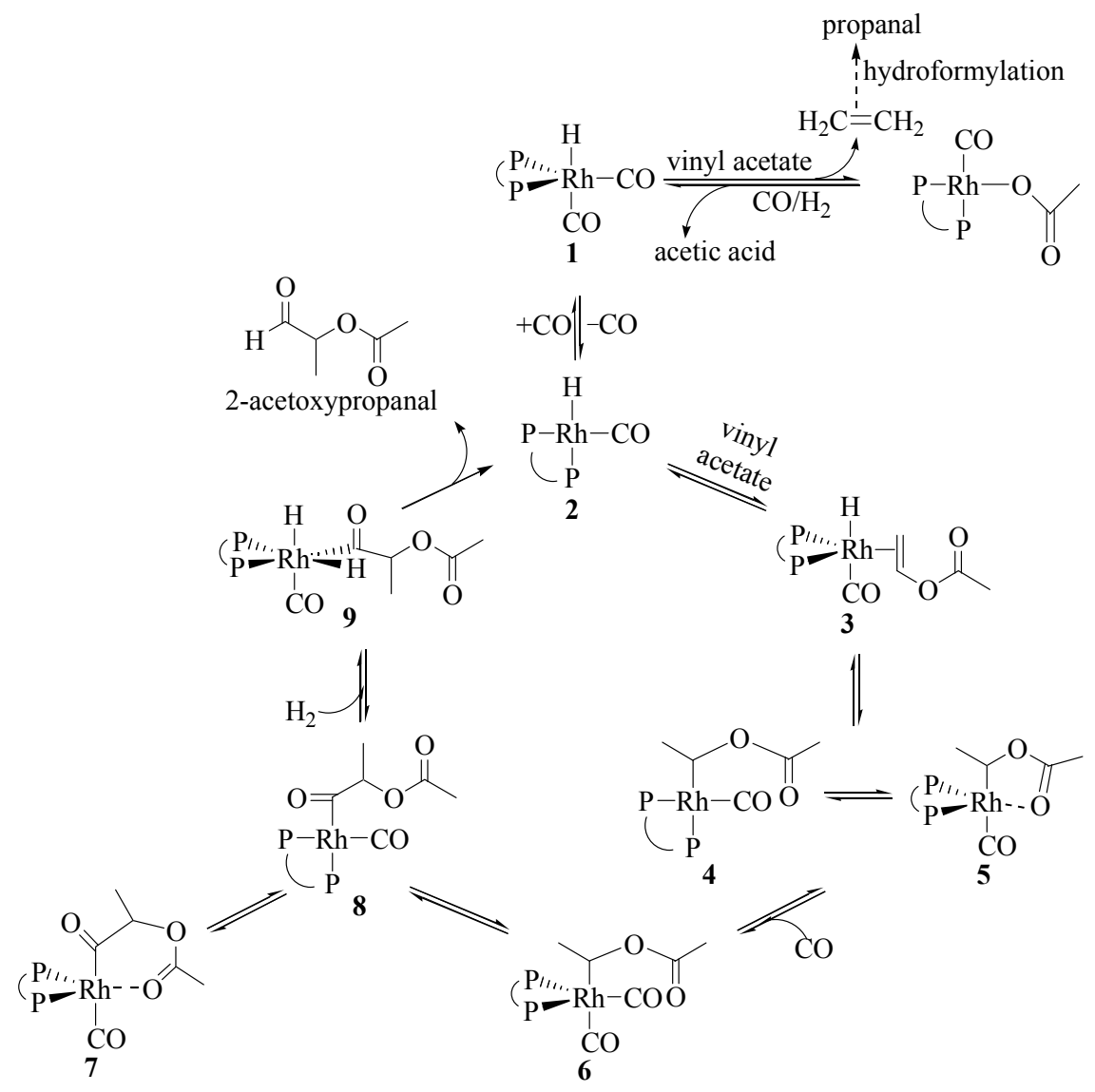

Scheme 2. Mechanism for vinyl acetate hydroformylation. 


\subsection{Catalyst stability}

In order to investigate the industrial potential of the $\mathrm{Rh}(\mathrm{CO})_{2}$ (acac)/BISBI catalyst, vinyl acetate hydroformylation was carried out under mild conditions $\left(80^{\circ} \mathrm{C}\right)$ for a prolonged reaction time. The results are summarized in Fig. 1. The TON increased to more than 9200 (conversion > $90 \%$ ) and the high selectivity was still maintained (up to $90 \%$ ) after the prolonged time $(12 \mathrm{~h})$, whereas the TON reported previously with the rhodium complex of monodentate phosphite $\mathrm{P}(\mathrm{ONp})_{3}$ catalyst was less than 2000 [12]. Therefore, catalyst $\mathrm{Rh}(\mathrm{CO})_{2}(\mathrm{acac}) / \mathrm{BISBI}$ showed better stability.

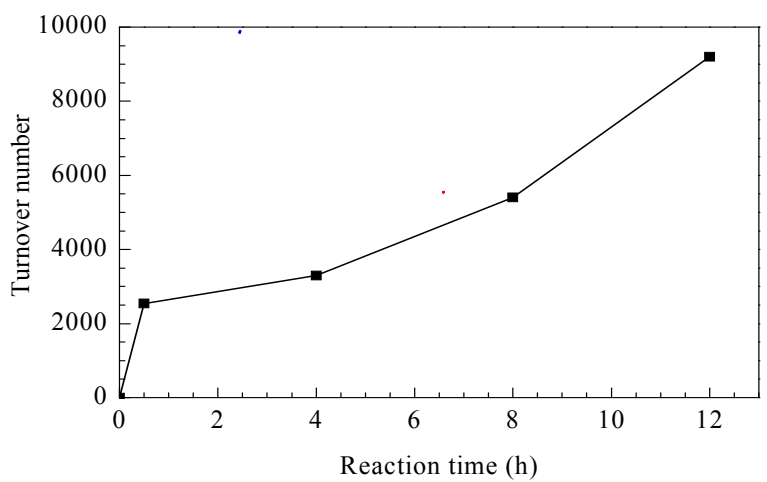

Fig. 1. Hydroformylation of vinyl acetate for a prolonged reaction time. Reaction conditions: vinyl acetate $=27 \mathrm{mmol},[\mathrm{Rh}]=1.4$ $\mathrm{mmol} / \mathrm{L}, \mathrm{S}: \mathrm{C}=10000,80^{\circ} \mathrm{C}, 5 \mathrm{MPa}\left(\mathrm{CO}: \mathrm{H}_{2}=1\right),[\mathrm{BISBI}]:[\mathrm{Rh}]=1$.

\section{Conclusions}

The use of a diphosphine ligand (BISBI, BINAP, P-Phos) in the Rh-catalyzed hydroformylation of vinyl acetate gave excellent catalytic activity and high regioselectivity. A catalytic mechanism was proposed. The high stability of the $\mathrm{Rh} / \mathrm{BISBI}$ catalyst indicated it can be used in practical applications of vinyl acetate hydroformylation. Future studies will focus on the altering of the ligand basicity by altering the chelating $\mathrm{P}$ substituent to give different regioselectivities.

\section{References}

1 Van Leeuwen P W N M, Claver C. Rhodium Catalyzed Hydroformylation. Amsterdam: Kluwer Academic Publishers, 2000. 2

2 Saidi O, Liu S F, Xiao J L. J Mol Catal A, 2009, 305: 130
3 Yu S C, Chie Y M, Zhang X M. Adv Synth Catal, 2009, 351: 537

4 Noonan G M, Newton D, Cobley C J, Suarez A, Pizzano A, Clarke M L. Adv Synth Catal, 2010, 352: 1047

5 Panda A G, Tambade P J, Patil Y P, Bhanage B M. Reac Kinet Mech Catal, 2010, 99: 143

6 Reynhardt J P K, Yang Y, Sayari A, Alper H. Chem Mater, 2004, 16: 4095

7 Borole Y L, Chaudhari R V. Ind Eng Chem Res, 2005, 44: 9601

8 Sudheesh N, Chaturvedi A K, Shukla R S. Appl Catal A, 2011, 409-410: 99

9 Abatjoglou A G, Bryant D R, D'Esposito L C. J Mol Catal, 1983, 18: 381

10 Williams D B G, Ajam M, Ranwell A. Organometallics, 2007, 26: 4692

11 Panda A G, Patil Y P, Tambade P J, Bhanage B M. Ind Eng Chem Res, 2010, 49: 8360

12 Dabbawala A A, Jasra R V, Bajaj H C. Catal Commun, 2010, 11: 616

13 刘雯静, 袁茂林, 付海燕, 李瑞祥, 陈华. 催化学报 (Liu W J, Yuan M L, Fu H Y, Li R X, Chen H. Chin J Catal), 2009, 30: 577

14 张林, 李春, 付海燕, 袁茂林, 李瑞祥, 陈华. 催化学报 (Zhang L, Li Ch, Fu H Y, Yuan M L, Li R X, Chen H. Chin J Catal), 2011, 32: 299

15 Breeden S, Cole-Hamilton D J, Foster D F, Schwarz G J, Wills M. Angew Chem, Int Ed, 2000, 39: 4106

16 Clark T P, Landis C R, Freed S L, Klosin J, Abboud K A. J Am Chem Soc, 2005, 127: 5040

17 Axtell A T, Cobley C J, Klosin J, Whiteker G T, Zanotti-Gerosa A, Abboud K A. Angew Chem, Int Ed, 2005, 44: 5834

18 Tomas P J, Axtell A T, Klosin J, Peng W, Rand C L, Clark T P, Landis C R, Abboud K A. Org Lett, 2007, 9: 2665

19 Chen H, Li Y Z, Li R X, Cheng P M, Li X J. J Mol Catal A, 2003, 198: 1

20 Wang X, Fu H Y, Li X J, Chen H. Catal Commun, 2004, 5: 739

21 Lin Q, Jiang W D, Fu H Y, Chen H, Li X J. Appl Catal A, 2007, 328: 83

22 Devon T J, Phillips G W, Puckette T A, Stavinoha J L, Vanderbilt J J. US 4694 109. 1987

23 Bonati F, Wilkinson G. J Chem Soc, 1964, 86: 3156

24 Deshpande R M, Chaudhari R V. J Mol Catal, 1989, 57: 177

25 Piras I, Jennerjahn R, Jackstell R, Spannenberg A, Franke R, Beller M. Angew Chem, 2011, 123: 294

26 Casey C P, Whiteker G T, Melville M G, Petrovich L M, Gavney J J A, Powell D R. J Am Chem Soc, 1992, 114: 5535 